\title{
Nuclear receptor retinoid-related orphan receptor alpha promotes apoptosis but is reduced in human gastric cancer
}

\author{
Zhengguang Wang ${ }^{1}$, Fangyuan Xiong ${ }^{2}$, Xiaoshan Wang ${ }^{1}$, Yijun $Q^{i}{ }^{1}$, Haoyuan $\mathbf{Y u}^{1}$, \\ Yong Zhu ${ }^{1}$, Huaqing Zhu ${ }^{2}$ \\ ${ }^{1}$ Department of Surgery, First Affiliated Hospital of Anhui Medical University, Hefei, Anhui, P.R. China \\ ${ }^{2}$ Laboratory of Molecular Biology and Department of Biochemistry, Anhui Medical University, Hefei, Anhui, P.R. China
}

Correspondence to: Zhengguang Wang, email: wangzhengguang@ahmu.edu.cn

Keywords: gastric carcinoma, RORa, AMPK, apoptosis, chemotherapy resistance

Received: November 02, 2016

Accepted: December 23, 2016

Published: December 29, 2016

\section{ABSTRACT}

Retinoid-related orphan receptor a (RORa) is a nuclear receptor, which regulates inflammation and immune responses, lipid metabolism and circadian rhythm. Although RORa suppresses breast tumor invasion, it is unknown whether RORa is dysregulated in gastric cancer leading to cellular survival. Therefore, we hypothesize that RORa is dysfunctional in gastric carcinoma and this causes decreased apoptosis in gastric cancer cells. To test this hypothesis, we employed human gastric cancer tissues with different stages to determine RORa expression, as well as in vitro human gastric cancer cells to determine how RORa is reduced during apoptosis. We found that the expression of RORa was reduced in gastric tissues with cancer, and this correlated with increased TNM stages. The mechanisms underlying RORa reduction is due to the reduced activation of AMP-activated protein kinase (AMPK), as a selective AMPK activator AICAR increased RORa activation and level in human gastric cancer cells. Furthermore, AICAR treatment increased RORa recruitment on the promoters of tumor suppressor genes (i.e., FBXM7, SEMA3F and p21) leading to apoptosis in human gastric cancer cells. Taken together, RORa reduction occurs in gastric cancer leading to the survival of tumor cells, which is attenuated by AMPK. Therefore, both RORa and AMPK are potential targets for the intervention and therapy in gastric carcinoma.

\section{INTRODUCTION}

Gastric cancer is the fourth most common cancer and is the third leading cause of cancer, with more than 700,000 deaths every year all over the world [1-3]. Despite the declined incidence and mortality due to the major improvements in diagnosis and treatment, there are less than $20 \%$ of patients with gastric cancer surviving up to 5 years [1]. Gastric cancer is usually treated with chemotherapy and surgery, but chemoresistance seriously hinders the treatment of gastric cancer. Therefore, it is an urgent to develop a novel chemotherapy or chemosensitizer in enhancing the chemosensitization.

Retinoic acid-related orphan receptor alpha $(\operatorname{ROR} \alpha)$ encoded by NR1F1 gene is a nuclear receptor in the ROR sub-family [4]. It is well-known that ROR $\alpha$ regulates inflammation and immune responses, lipid metabolism and circadian rhythm [5-8]. Recent studies have shown that $\mathrm{ROR} \alpha$ is associated with cancer prognosis through the modulation of cell proliferation [9-13]. However, there are no reports regarding the regulation of $\mathrm{ROR} \alpha$ in gastric cancer and whether ROR $\alpha$ modulates apoptosis in gastric cancer cells. We hypothesize that ROR $\alpha$ is dysregulated in gastric cancer and this dysregulation reduces the apoptosis in gastric cancer cells. To test this hypothesis, the mRNA and protein levels were determined in human gastric cancer tissues with different stages. We also employed the gastric cancer cell lines to determine the mechanisms for $\operatorname{ROR} \alpha$ dysregulation and whether $\operatorname{ROR} \alpha$ promotes apoptosis.

\section{RESULTS}

Expression of ROR $\alpha$ was reduced in human gastric cancer tissues

To test the role of ROR $\alpha$ in human gastric cancer, the abundance of $\operatorname{ROR} \alpha$ in gastric tissues adjacent to 
cancer (normal) and with different clinical stages of gastric carcinoma was determined by immunohistochemistry. As shown on Figure $1 \mathrm{~A}$ and $1 \mathrm{~B}$, the expression of ROR $\alpha$ was significantly reduced in gastric cancer tissues compared to non-cancer gastric tissues. The reduction of $\mathrm{ROR} \alpha$ abundance was associated with disease stage. Similarly, the reduction of $\mathrm{ROR} \alpha$ abundance in gastric cancer tissues was confirmed by Western blot (Figure 1C and 1D). Furthermore, we measured ROR $\alpha$ mRNA level in gastric cancer tissues and matched adjacent gastric mucosa. In consistent with the above findings, the expression of ROR $\alpha$ mRNA was significantly down-regulated in gastric cancer compared with matched adjacent gastric mucosa (Figure 1E). These results suggest the significant reduction of ROR $\alpha$ in gastric cancer tissues, which is associated with the clinic stage.

\section{Association of ROR $\alpha$ expression with clinicopathological factors}

To determine the clinical significance of $\operatorname{ROR} \alpha$, we analyzed the correlations between the ROR $\alpha$ level and clinicopathological factors in according to immunohistochemistry results (Table 1). Low expression of ROR $\alpha$ protein was significantly associated with tumor size, tumor differentiation, T stage, TNM stage, and lymph node metastasis. The results indicate that $\mathrm{ROR} \alpha$ level is associated with the progression and prognosis of gastric cancer.

\section{Expression of ROR $\alpha$ was reduced in human gastric cancer cell lines}

To further determine the association of ROR $\alpha$ with gastric cancer, we employed human gastric cancer cell lines. As shown in Figure 2A and 2B, the protein levels of ROR $\alpha$ determined by Western blot were significantly reduced in human gastric cancer cells SGC-7901 and AGS cells as compared to normal gastric epithelial cells GES-1. Similarly, the mRNA level of ROR $\alpha$ was decreased in SGC-7901, AGS, MKN-28 and MKN-45 compared with GES-1 cells (Figure 2C). These data further demonstrate the significant reduction of ROR $\alpha$ in gastric cancer cells.

\section{AMP-activated protein kinase (AMPK) promoted ROR $\alpha$ activation and levels in gastric carcinoma cells}

We and others have shown that AMPK reduction in gastric cancer, which regulates cancer cell proliferation and apoptosis [14-16]. Hence, we hypothesized that AMPK modulates ROR $\alpha$ activity and level. To test this hypothesis, we first employed the co-immunoprecipitation (Co-IP) approach to detect the physical interaction of AMPK and ROR $\alpha$ in SGC-7901 cells. As shown in Figure 3A and $3 \mathrm{~B}$, the interaction of AMPK and ROR $\alpha$ was observed in normal gastric epithelial cells GES-1. This ratio of ROR $\alpha$ to AMPK blot was significantly reduced in SGC7901 and AGS cells. Next we treated SGC-7901 cells with a selective AMPK activator AICAR (1 mM, $48 \mathrm{~h})$, and then determined ROR $\alpha$ phosphorylation by Western blot. As shown in Figure 3C and 3D, AICAR treatment significantly increased the phosphorylation of $\mathrm{ROR} \alpha$ (Ser 35), suggesting its activation [11]. Furthermore, we also observed increased levels of ROR $\alpha$ mRNA in SGC7901 cells treated with AICAR (1 mM, 48 h) (Figure 3E).

AMPK has been shown to increase the expression of tumor suppressor genes including F-box and WD repeat domain containing 7 (FBXW7), semaphorin III/F (SEMA3F), and $\mathrm{p} 21^{\mathrm{Cip} 1}(\mathrm{p} 21)$ in gastric cancer cells,
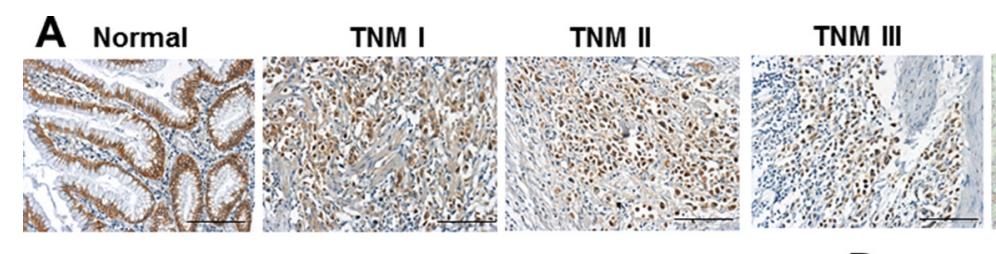

TNM IV

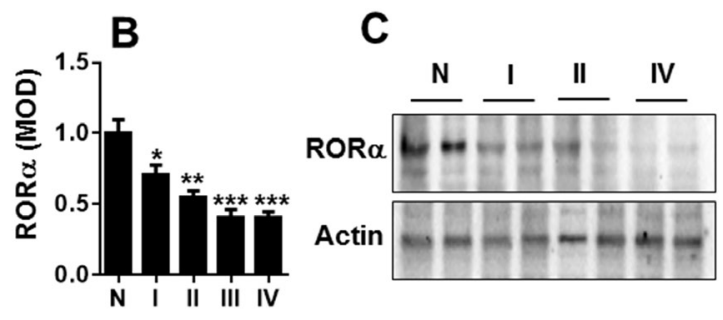

D

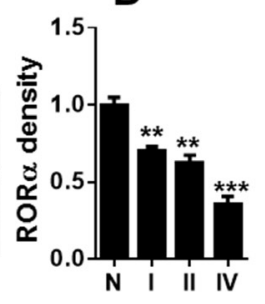

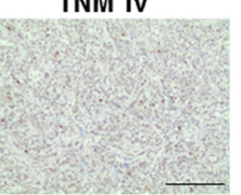

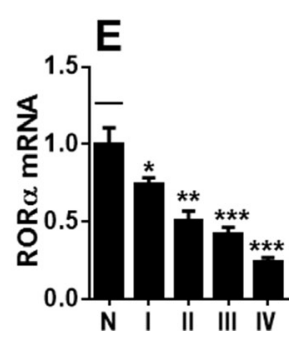

Figure 1: ROR $\boldsymbol{\alpha}$ was reduced in human gastric cancer. (A) Representative IHC results showing the expression of ROR $\alpha$ in human gastric tissues adjacent to tumor (Normal, N) and with cancer from TNM I to TNM IV. Bar size: $100 \mu$ M. (B) The MOD showing the changes in ROR $\alpha$ expression by immunohistochemistry in A. (C) Representative Western blots showing the changes of ROR $\alpha$ levels in human gastric tissues adjacent to tumor (Normal, N) and with cancer from TNM I to TNM IV. $\beta$-actin was used a loading control. (D) The densitometry of ROR $\alpha$ bands in C. Relative protein expression of ROR $\alpha$ was normalized to that of $\beta$-actin. (E) The levels of ROR $\alpha$ mRNA in human gastric tissues adjacent to tumor (Normal, N) and with cancer from TNM I to TNM IV, which was measured by qPCR. 18S rRNA was used a housekeeping gene. Data are expressed as the mean \pm SEM. $N=3-6$. ${ }^{*} P<0.05, * * P<0.01, * * * P<0.001$, vs. Normal. 
Table 1: Relationship of $\mathrm{ROR} \alpha$ expression to clinicopathological variables

\begin{tabular}{|c|c|c|c|c|c|}
\hline Variables & & $\begin{array}{c}\text { Numbers of } \\
\text { patients }(n=74)\end{array}$ & $\begin{array}{c}\text { Low RORa } \\
\text { levels }(n=43)\end{array}$ & $\begin{array}{c}\text { High ROR } \alpha \\
\text { levels }(n=31)\end{array}$ & $P$ value \\
\hline \multirow[t]{2}{*}{ Sex } & Male & 58 & 35 & 23 & 0.458 \\
\hline & Female & 16 & 8 & 8 & \\
\hline \multirow[t]{2}{*}{ Age (years) } & $<60$ & 23 & 16 & 7 & 0.180 \\
\hline & $\geq 60$ & 51 & 27 & 24 & \\
\hline \multirow[t]{4}{*}{ Primary tumor site } & Gastric cardia & 33 & 20 & 13 & 0.489 \\
\hline & Gastric antrum & 21 & 9 & 12 & \\
\hline & Gastric body & 17 & 12 & 5 & \\
\hline & Gastric fundus & 3 & 2 & 1 & \\
\hline \multirow[t]{2}{*}{ Diameter of tumor } & $<5 \mathrm{~cm}$ & 31 & 13 & 18 & 0.017 \\
\hline & $\geq 5 \mathrm{~cm}$ & 43 & 30 & 13 & \\
\hline \multirow[t]{2}{*}{ Adenocarcinoma } & Moderately differentiated & 22 & 8 & 14 & 0.014 \\
\hline & Poorly differentiated & 52 & 35 & 17 & \\
\hline \multirow[t]{4}{*}{ T stage } & $\mathrm{T} 1$ & 9 & 0 & 9 & 0.001 \\
\hline & $\mathrm{T} 2$ & 6 & 3 & 3 & \\
\hline & T3 & 38 & 24 & 14 & \\
\hline & $\mathrm{T} 4$ & 21 & 16 & 5 & \\
\hline \multirow[t]{4}{*}{ TNM stage } & I & 11 & 3 & 8 & 0.023 \\
\hline & II & 7 & 2 & 5 & \\
\hline & III & 32 & 23 & 9 & \\
\hline & IV & 24 & 15 & 9 & \\
\hline \multirow[t]{2}{*}{$\begin{array}{l}\text { Lymph node } \\
\text { metastasis }\end{array}$} & Present & 58 & 38 & 20 & 0.009 \\
\hline & Absent & 16 & 5 & 11 & \\
\hline
\end{tabular}

and $\operatorname{ROR} \alpha$ functions a transcription activator $[14,17]$. Therefore, we hypothesized that ROR $\alpha$ activation by AMPK enhances its recruitment on the promoters of these genes. The chromatin immunoprecipitation (ChIP) was performed to determine the recruitment of $\mathrm{ROR} \alpha$ on the promoters of FBXW7, SEMA3F, and p21 genes in SGC7901 cells treated with AICAR ( $1 \mathrm{mM}, 48 \mathrm{~h})$. As shown in Figure 3F, AICAR treatment enhances the recruitment of ROR $\alpha$ on the promoters of FBXW7, SEMA3F, and p21 genes in SGC-7901 cells. Altogether, these results suggest that the ROR $\alpha$ reduction in gastric cancer is possible due to the decrease in AMPK, which leads to its recruitment on tumor suppressor genes.

\section{Effect of ROR $\alpha$ on the apoptosis in SGC-7901 cells}

To determine the role of ROR $\alpha$ in apoptosis, we transfected its siRNA into SGC-7901 and measured the apoptosis using a photometric ELISA assay. As shown in Figure 4A, transfection with ROR $\alpha$ siRNA significantly decreased AICAR-induced apoptosis in SGC-7901 cells as compared to scrambled siRNA control. Treatment with ROR $\alpha$ agonist SR1001 increased apoptosis in SGC-7901 cells, whereas its reverse agonist SR3335 reduced 5-FUmediated apoptosis (Figure 4B). These data implicate that $\mathrm{ROR} \alpha$ promotes apoptosis in human gastric cancer cells.

\section{DISCUSSION}

In the present study, we have shown the novel role of ROR $\alpha$ in human gastric cancer. ROR $\alpha$ was downregulated in human gastric cancer tissues, and this reduction was associated with the progression and poor prognosis. The mechanisms underlying $\mathrm{ROR} \alpha$ reduction in human gastric cancer were due to the decreased AMPK, leading to less apoptosis (Figure 5).

There are three ROR families including $\mathrm{ROR} \alpha$, $\operatorname{ROR} \beta$, and $\operatorname{ROR} \gamma$, and all are transcriptional activators recognizing ROR-response elements [6]. ROR $\alpha$ is expressed in a variety of cell types including gastric epithelial cells [18]. It has been shown that $\mathrm{ROR} \alpha$ regulates several cellular processes involved in development, circadian rhythm, and inflammatory responses [5-7]. 
Recent studies suggest the potential role of ROR $\alpha$ in progression and prognosis of cancer including colon cancer and breast cancer $[11,19,20]$, and that $\operatorname{ROR} \alpha$ functions as suppression of tumor cell proliferation and augmentation of apoptosis [12, 18, 21-24]. Our study here for the first time demonstrated that $\mathrm{ROR} \alpha$ was significantly reduced in human gastric cancer tissues, which is associated with the clinical stages and lymph node metastasis. These findings provide the possibility of ROR $\alpha$ as a biomarker of severity and prognosis of gastric cancer, although the follow-up experiments to monitor the survival duration of patients with low and high expression of $\operatorname{ROR} \alpha$.
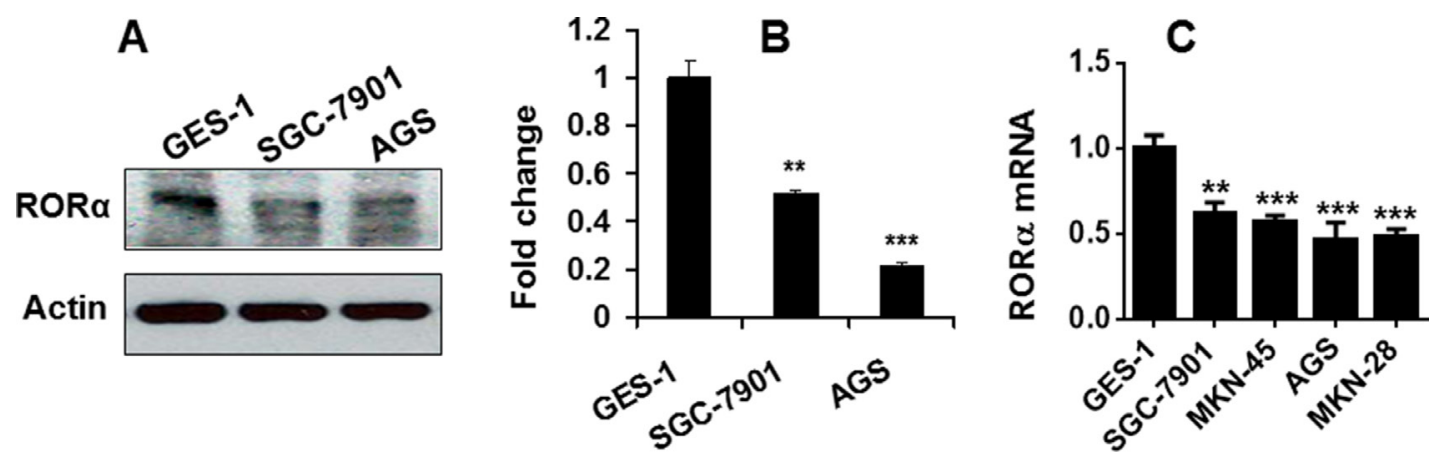

Figure 2: ROR $\alpha$ was reduced in human gastric cancer cell lines. (A) ROR $\alpha$ protein levels determined by Western bolts in human gastric epithelial cells (GES-1) and gastric cancer cell lines (SGC-7901 and AGS). $\beta$-actin was used a loading control. (B) The densitometry of ROR $\alpha$ bands in A. Relative protein expression of ROR $\alpha$ was normalized to that of $\beta$-actin. (C) ROR $\alpha$ mRNA expression determined by qPCR in human gastric epithelial cells (GES-1) and gastric cancer cell lines (SGC-7901, MKN-45, AGS, and MKN-28). 18S rRNA was used a housekeeping gene. Data are expressed as the mean \pm SEM. $N=3-6$. $* * P<0.01, * * * P<0.001$, vs. GES- 1 cells.

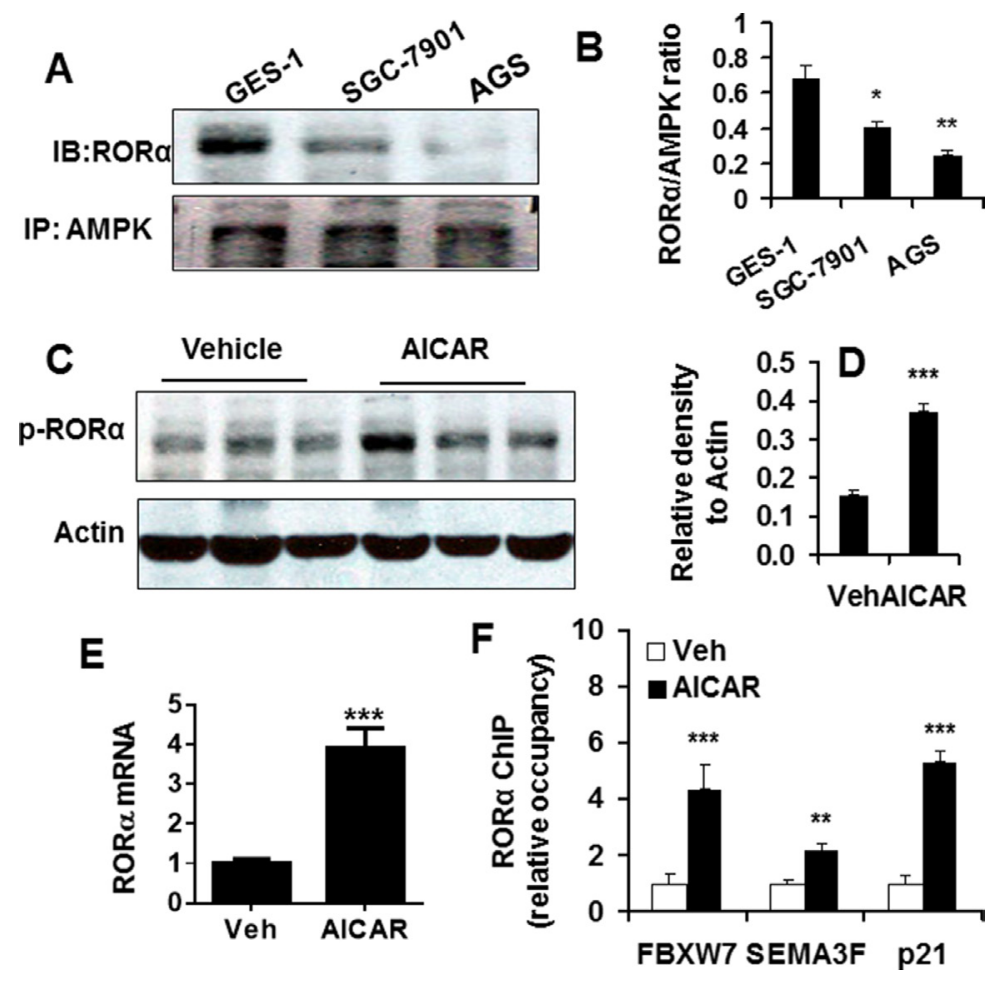

Figure 3: AMPK interacted ROR $\alpha$ and regulated its activity and levels. (A) Physical interaction of ROR $\alpha$ (IB) with AMPK (IP) was determined by co-immunoprecipitation, and representative bands were shown. (B) Densitometry of ROR $\alpha$ to AMPK ratio was shown. Data are expressed as the mean \pm SEM. $N=3$. $* P<0.05$, $* * P<0.01$, vs. GES-1 cells. (C) ROR $\alpha$ phosphorylation determined by Western blot in SGC-7901 cells treated with AICAR ( $1 \mathrm{mM}$ for $48 \mathrm{~h}$ ). $\beta$-actin was used a loading control. (D) The densitometry of ROR $\alpha$ phosphorylation bands after normalization with $\beta$-actin. $* * * P<0.001$, vs. vehicle. (E) ROR $\alpha$ mRNA determined by qPCR in SGC-7901 cells treated with AICAR ( $1 \mathrm{mM}$ for $48 \mathrm{~h}$ ). $18 \mathrm{~S}$ rRNA was used a housekeeping gene. ${ }^{* * *} P<0.001$, vs. vehicle (Veh). (F) Changes in ROR $\alpha$ recruitment on the promoters of FBXW7, SEMA3F, and p21 genes, which is determined by ChIP, in SGC-7901 cells treated with $\operatorname{AICAR}(1 \mathrm{mM}$ for $48 \mathrm{~h}$ ). ChIP analysis was performed using ROR $\alpha$ antibody or normal serum IgG (as control) as described in materials and methods. $* * P<0.01, * * * P<0.001$, vs. corresponding vehicle (Veh) controls. 
ROR $\alpha$ plays an important role in increasing apoptosis, which forms a basis for its tumor-suppressive regulatory role $[21,24]$. We employed both genetic and pharmacological approaches to determine the role of $\mathrm{ROR} \alpha$ in regulating apoptosis in gastric cancer cells. We found that $\mathrm{ROR} \alpha$ activation induced apoptosis, whereas its knockdown by siRNA or pharmacological inhibition reduced apoptosis in gastric cancer cells. This may serve a mechanism for progression of gastric cancer through reduced apoptosis in cancer cells when ROR $\alpha$ is significantly ameliorated. Furthermore, our study showed that $\mathrm{ROR} \alpha$ can be recruited on the promoter of tumor suppressor genes including FBXW7, SEMA3F, and $\mathrm{p} 21$. As a transcription activator, $\mathrm{ROR} \alpha$ reduction may reduce the transcription of these tumor suppressor genes, resulting in cancer progression. This is consistent with the finding showing SEMA3F, a direct ROR $\alpha$ target gene with a ROR element, suppresses breast tumor invasion $[12,23]$. The ongoing experiment is to investigate whether ROR $\alpha$ stabilize p53 therefore modulating apoptosis [24]. Further study is required to determine the role of $\mathrm{ROR} \alpha$ in regulating proliferation, migration, invasion of gastric cancer cells, and chemotherapy sensitivity, as well as in animal model of gastric cancer. Recent studies have shown that in hepatoma cells ROR $\alpha$ reprograms glycolysis that is upregulated in gastric cancer for cell proliferation (Warburg effect) $[25,26]$. It remains unknown whether $\mathrm{ROR} \alpha$ reduces glycolysis in gastric cancer thereby reducing their proliferation.

In the present study, we found that $\mathrm{ROR} \alpha$ can be posttranslationally regulated by AMPK, as AMPK activator AICAR treatment increased $\mathrm{ROR} \alpha$ phosphorylation (Ser35). This is further confirmed by the experiment showing the physical interaction of ROR $\alpha$ with AMPK in normal gastric epithelial cells. This interaction was reduced in gastric cancer cells. The levels of AMPK $\alpha$ are decreased in the early stage of gastric cancer, and patients with gastric carcinoma often have a favorable prognosis with positive expression of AMPK [15, 16, 27, 28], suggesting the reduced ROR $\alpha$ phosphorylation/activation in gastric cancer. In addition to phosphorylation, ROR $\alpha$ mRNA was also augmented in gastric cancer cells treated with AICAR,
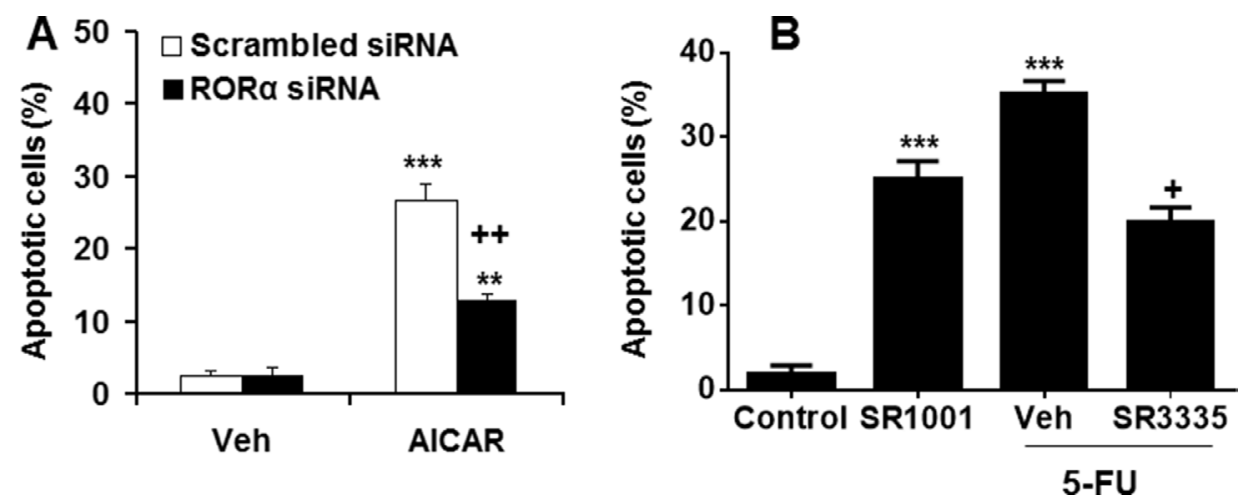

Figure 4: ROR $\alpha$ regulated apoptosis in human gastric cancer cells. (A) Transfection with ROR $\alpha$ siRNA reduced apoptosis in SGC-7901 cells induced by AMPK activator AICAR ( $1 \mathrm{mM}$ for $48 \mathrm{~h}) . * * P<0.01$ and ${ }^{* * *} P<0.001$ vs. vehicle (Veh); ${ }^{*+} P<0.01 \mathrm{versus}$ Scrambled siRNA/AICAR group. (B) Treatment of ROR $\alpha$ agonist (SR1001) induced apoptosis, whereas ROR $\alpha$ reverse agonist (SR3335) attenuated 5-FU-induced apoptosis in SGC-7901 cells. $* * * P<0.001$ vs. control; ${ }^{+} P<0.05$ versus 5-FU alone.

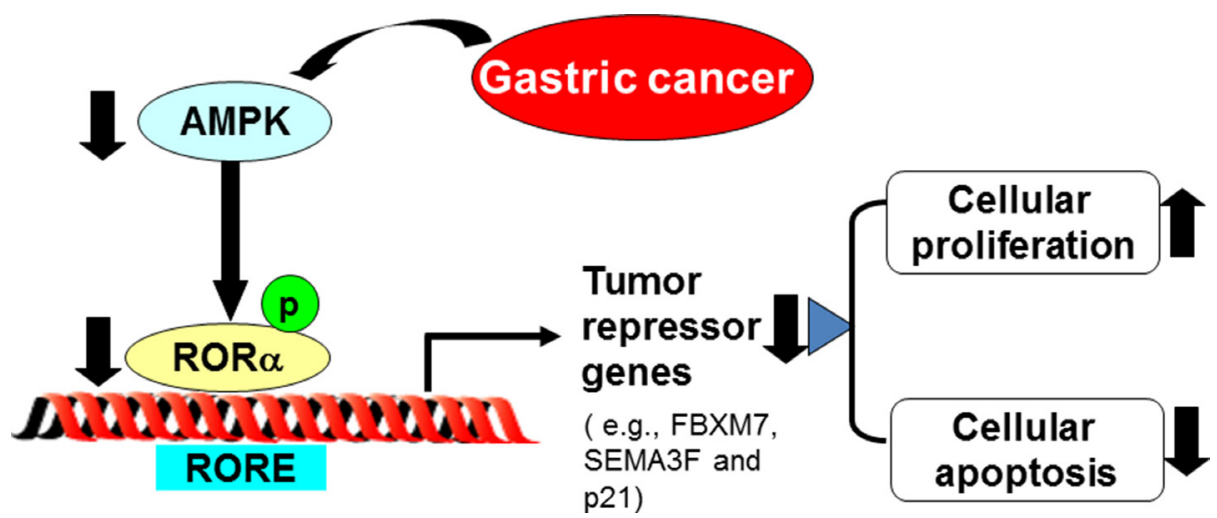

Figure 5: Schematic figure of our findings. ROR $\alpha$ was down-regulated in human gastric cancer tissues, which was associated with the progression and poor prognosis. This is due to the decreased AMPK, leading to less expression of tumor repressor gene and apoptosis. 
although AMPK siRNA or overexpression approaches would further support these data. The mechanisms underlying these findings need to be identified. ROR $\alpha$ has been shown to activate AMPK in liver tissues [29], which raises the question whether there have a positive feedback between AMPK and ROR $\alpha$ in regulating the progression of human gastric cancer. Overall, these finding suggest that AMPK regulates ROR $\alpha$ through both transcription and posttranslational modifications, and that $\mathrm{ROR} \alpha$ may be a potential novel therapeutic target for AMPK-induced apoptosis in gastric cancer cells.

In summary, ROR $\alpha$ is down-regulated in human gastric cancer, which causes the resistance to apoptosis in gastric cancer cells. Mechanistically, AMPK reduction leads to the decreased activation and transcription of ROR $\alpha$, resulting in the expression of tumor suppresser genes. Utilization of $\mathrm{ROR} \alpha$ agonist or AMPK activator would be a potential therapeutic strategy for the treatment of gastric cancer.

\section{MATERIALS AND METHODS}

\section{Patients and tissue collection}

Eligible 74 patients were adults (18 years old to 75 years old) with biopsy-confirmed gastric adenocarcinoma with histological examination. All enrolled patients underwent total or subtotal gastrectomy since 2014. None of the patients had received radiotherapy or chemotherapy before surgery. After surgery, each patient received chemotherapy with the regimens of FOLFOX4 program. The clinical characteristics were shown in Table 1. All patients had normal hepatic, renal and bone marrow function, as well as ECOG performance status between 0-2. Patients were excluded for serious disorders, peripheral neuropathy (NCI-CTC1 level and above), pregnancy, or breast-feeding.

All patients were screened and treated for the purpose of the study at the Affiliated Hospital of Anhui Medical University, Hefei, China, and signed an informed consent form. The human ethics guidelines was discussed and approved by the Human Ethics Committee in the First Affiliated Hospital of Anhui Medical University [30].

\section{Immunohistochemistry}

The expression of ROR $\alpha$ in normal gastric tissues and gastric carcinoma tissues with different clinical stages were measured by immuohistochemistery [30]. The specimens were blocked with $3 \%$ hydrogen peroxide, $10 \%$ normal goat serum, and then incubated with the ROR $\alpha$ antibody (1:500 dilutions, Abcam, USA) overnight at $4^{\circ} \mathrm{C}$. After treated with biotin-conjugated secondary antibody, the slides were incubated with streptavidin-biotin horseradish peroxidase complex, followed by incubation with diaminobenzidine (DAB, ZSGB-BIO, China) for $5 \mathrm{~min}$.
The counterstaining with hematoxylin was then performed, and slides were observed under a bright-field microscope in a double-blinded manner. The integral optical density value of all images was analyzed, and relative protein expression levels were densitometrically calculated and expressed in the mean optical density (MOD) units $[30,31]$. The staining intensity was scored as ' 0 ' (no staining), ' 1 ' $(\leq 25 \%$, weakly stained), ' 2 ' ( $25 \%-50 \%$, moderately stained), or ' 3 ' $(\geq 50 \%$, strongly stained). A low ROR $\alpha$ expression was defined as score ' 0 ' or ' 1 , and a high ROR $\alpha$ expression was defined as score ' 2 ' or ' 3 '. The patients were then divided into two groups: ROR $\alpha$ high expression group $(n=31)$ and $\mathrm{ROR} \alpha$ low expression group $(n=43)$ (Table 1).

\section{Cell treatment and transfection}

Gastric carcinoma cells (SGC-7901, AGS, MKN-28, and $\mathrm{MKN}-45)$ and human gastric epithelial cell line (GES-1) were purchased from the American Type Culture Collection (ATCC, USA). These cells were maintained on tissue culture flask, propagated in DMEM medium with $10 \% \mathrm{FBS}$, penicillin $(100 \mathrm{U} / \mathrm{ml})$, and streptomycin $(100 \mathrm{U} / \mathrm{ml})$ in $5 \% \mathrm{CO}_{2}$ and humid air at $37^{\circ} \mathrm{C}$. Cells were split every 2-3 days by trypsinization and centrifugation, followed by aspiration of the culture medium. In a separate experiment, SGC-7901 cells were plated in 6 -well plates at a density of $1 \times 10^{6}$ cells $/ 2 \mathrm{ml}$ media, and then treated with a selective activator of AMPK, which was 5-aminoimidazole-4-carboxyamide ribonucleoside (AICAR) (1 mM, Sigma, USA), or with specific ROR $\alpha$ agonist (SR1001, $0.5 \mu \mathrm{M}$, Cayman, USA) and reverse agonist (SR3335, $0.5 \mu \mathrm{M}$, Cayman, USA) for $48 \mathrm{~h}$ [14]. To reduce endogenous ROR expression, SGC-7901 cells were seeded onto a 12 -well plate $\left(5 \times 10^{5} /\right.$ well $)$ and transfected with human ROR $\alpha$ siRNA (Dharmacon RNA Technologies, Lafayette, CO, USA) at $50 \mathrm{nM}$ using the Lipofectamine reagent (Invitrogen, Carlsbad, CA, USA) according to the instructions. Twenty-four hours after transfection, cells were treated with vehicle or AICAR (1 $\mathrm{mM})$ for $48 \mathrm{~h}$.

\section{Western blot analysis}

Gastric tissues and cells were lysed in RIPA buffer (Tris-HCl, pH 7.14, 150 mmol/L NaCl, 1 mmol/L EDTA, $1 \%$ Triton, $0.1 \%$ SDS, $5 \mathrm{mg} / \mathrm{ml}$ Leupeptin, and $1 \mathrm{mmol} / \mathrm{L}$ PMSF). After repetitive freeze-thawing for 3 times, the lysates were centrifuged at $14,000 \mathrm{rpm}$ for $10 \mathrm{~min}$ at $4^{\circ} \mathrm{C}$. The protein concentration of the sample was measured with Micro-BCA Protein Assay Reagent Kit (Beyotime, China). Protein extracts were separated through 12\% SDS-PAGE and transferred to polyvinylidene fluoride membranes. The membrane was blocked with 5\% fatfree milk in TBST (PBS with 0.1\% Tween 20) for $2 \mathrm{~h}$ at room temperature. After washing 3 times (10 min each time) with TBST, the corresponding antibodies against 
$\operatorname{ROR} \alpha$ (1:1000 dilutions), p-ROR $\alpha$ (1:1000 dilutions), and actin (1:1000 dilutions, Santa Cruz Technology, USA) were incubated overnight at $4^{\circ} \mathrm{C}$. The membrane was incubated with the appropriate HRP-conjugated secondary antibodies (1:5,000 dilutions, Millipore) for $2 \mathrm{~h}$ at room temperature, and detected with enhanced chemiluminescence (ECL, Beyotime, China). Equal loading of the samples was determined by quantification of proteins as well as by reprobing membranes for a housekeeping control $\beta$-actin. The ImageJ software was used to quantify the densitometry of Western blot bands.

\section{Co-IP assay}

Gastric epithelial and cancer cells including GES-1, SGC-7901 and AGS lysed with RIPA buffer, and cell lysates were used for AMPK immunoprecipitation with a polyclonal antibody against AMPK (1:40 dilutions, Santa Cruz Biotechnology, USA), which was added to $150 \mu \mathrm{g}$ of sample proteins in a final volume of $200 \mu \mathrm{l}$, and incubated for $1 \mathrm{~h}$. Protein-A/G agarose beads $(10 \mu \mathrm{l})$ were added to each sample and kept overnight at $4^{\circ} \mathrm{C}$ on a rotating rocker. For immunoblot, the immunoprecipitated AMPK agarose bead suspension was resolved by SDSPAGE gradient gels. The membranes were blotted using the ROR $\alpha$ antibody. The densitometry of ROR $\alpha$ bands was normalized to AMPK with quantitative analysis using the Image J software.

\section{ChIP assay}

ChIP was performed according to the protocol as described previously $[32,33]$. Briefly, the lysates from SGC-7901 cells treated with an AMPK activator AICAR (1 $\mathrm{mM}, 48 \mathrm{~h})$ or vehicle were cross-linked with $1 \%$ formaldehyde for $10 \mathrm{~min}$. Cell pellets were resuspended with SDS-lysis buffer containing $50 \mathrm{mM}$ Tris-HCl, 1\% SDS, $5 \mathrm{mM}$ EDTA, $5 \mathrm{mM}$ sodium butyrate, and protease inhibitors, and sonicated four times for $30 \mathrm{sec}$ at a maximum speed using a Sonicator. Supernatants were precleared $t$ with $60 \mu \mathrm{l}$ of protein A agarose/salmon sperm DNA for $3 \mathrm{~h}$ at $4{ }^{\circ} \mathrm{C}$ [33]. After immunoprecipitation with ROR $\alpha$ antibody ( $1 \mu \mathrm{g})$ overnight, $40 \mu \mathrm{l}$ of protein A agarose/salmon sperm DNA was added and incubated for $2 \mathrm{~h}$. Precipitates were washed sequentially with Paro buffer I, Paro buffer II, and Paro buffer III for $5 \mathrm{~min}$ at $4^{\circ} \mathrm{C}$. The antigen-antibody complexes were extracted with $50 \mu 1$ elution buffer $(0.2 \mu \mathrm{g} / \mu \mathrm{l}$ proteinase $\mathrm{K}, 1 \% \mathrm{SDS}$, and $0.1 \mathrm{M} \mathrm{NaHCO}_{3}$ ). The eluted samples were incubated at $65^{\circ} \mathrm{C}$ overnight to reverse formaldehyde cross-linking. The recovered DNA was purified with a QIAquick PCR purification kit (Qiagen, Valencia, CA, USA). Samples of input DNA were also prepared in the same way as described above. Real-time PCR was performed to determine the expression of tumor suppressor genes FBXW7, SEMA3F, and p21 as described below.

\section{Quantitative real-time PCR}

Total RNA was isolated using TRIzol (Invitrogen, USA) according to the manufacturer's instructions. The cDNA was generated using a Transcriptor first-strand cDNA synthesis kit (TaKaRa, Shiga, Japan), and the primers for FBXW7, SEMA3F, and p21 were used for PCR amplification [14, 34-36]. Relative levels of specific mRNA were determined using the Thermo PIKOREAL 96 real-time PCR detection system with QIAGEN SYBR

${ }^{\circledR}$ Green supermix (Valencia, CA, USA) according to the manufacturer's instructions. The 18 rRNA gene was used as an internal control for normalization.

\section{Apoptosis assay}

The percentage of apoptotic cells was determined using a photometric ELISA assay from BoehringerMannheim that measures cytoplasmic histone-associated DNA fragments as previous work [37]. Optimal apoptotic response (assuming 100\% apoptotic cells) was observed after cell treatment with $50 \mu \mathrm{M}$ camptothecin for $24 \mathrm{~h}$, and this value was used to calculate the percentage of apoptotic SGC-7901 cells after the treatments.

\section{Statistical analysis}

Statistical analyses were employed by SPSS 19.0. The results were presented as mean \pm SEM. One-way analysis of variance (ANOVA) was used for the statistical significance of the differences between groups. The chisquare test was used to analyze the ROR $\alpha$ expression to clinicopathological variables. There existed statistical significance when $P<0.05$.

\section{ACKNOWLEDGMENTS AND FUNDING}

This study was supported by the Anhui Provincial Natural Science Foundation (1608085MH182).

\section{CONFLICTS OF INTEREST}

The authors confirm that there are no conflicts of interest.

\section{REFERENCES}

1. Bertuccio P, Chatenoud L, Levi F, Praud D, Ferlay J, Negri E, Malvezzi M, La Vecchia C. Recent patterns in gastric cancer: a global overview. Int J Cancer. 2009; 125:666-673.

2. Bosetti C, Bertuccio P, Malvezzi M, Levi F, Chatenoud L, Negri E, La Vecchia C. Cancer mortality in Europe, 2005-2009, and an overview of trends since 1980. Ann Oncol. 2013; 24:2657-2671. 
3. Peleteiro B, Severo M, La Vecchia C, Lunet N. Modelbased patterns in stomach cancer mortality worldwide. Eur J Cancer Prev. 2014; 23:524-531.

4. Solt LA, Burris TP. Action of RORs and their ligands in (patho) physiology. Trends Endocrinol Metab. 2012; 23:619-627.

5. Wong SH, Walker JA, Jolin HE, Drynan LF, Hams E, Camelo A, Barlow JL, Neill DR, Panova V, Koch U, Radtke F, Hardman CS, Hwang YY, et al. Transcription factor RORalpha is critical for nuocyte development. Nat Immunol. 2012; 13:229-236.

6. Zhao X, Cho H, Yu RT, Atkins AR, Downes M, Evans RM. Nuclear receptors rock around the clock. EMBO Rep. 2014; 15:518-528.

7. Kang HS, Okamoto K, Takeda Y, Beak JY, Gerrish K, Bortner CD, DeGraff LM, Wada T, Xie W, Jetten AM. Transcriptional profiling reveals a role for RORalpha in regulating gene expression in obesity-associated inflammation and hepatic steatosis. Physiol Genomics. 2011; 43:818-828.

8. Lau P, Fitzsimmons RL, Raichur S, Wang SC, Lechtken A, Muscat GE. The orphan nuclear receptor, RORalpha, regulates gene expression that controls lipid metabolism: staggerer (SG/SG) mice are resistant to diet-induced obesity. J Biol Chem. 2008; 283:18411-18421.

9. Fu RD, Qiu CH, Chen HA, Zhang ZG, Lu MQ. Retinoic acid receptor-related receptor alpha (RORalpha) is a prognostic marker for hepatocellular carcinoma. Tumour Biol. 2014; 35:7603-7610.

10. Xiao L, Wang J, Li J, Chen X, Xu P, Sun S, He D, Cong Y, Zhai Y. RORalpha inhibits adipocyte-conditioned mediuminduced colorectal cancer cell proliferation and migration and chick embryo chorioallantoic membrane angiopoiesis. Am J Physiol Cell Physiol. 2015; 308:C385-396.

11. Lee JM, Kim IS, Kim H, Lee JS, Kim K, Yim HY, Jeong J, Kim JH, Kim JY, Lee H, Seo SB, Kim H, Rosenfeld MG, et al. RORalpha attenuates Wnt/beta-catenin signaling by PKCalpha-dependent phosphorylation in colon cancer. Mol Cell. 2010; 37:183-195.

12. Du J, Xu R. RORalpha, a potential tumor suppressor and therapeutic target of breast cancer. Int J Mol Sci. 2012; 13:15755-15766.

13. Moretti RM, Marelli MM, Motta M, Polizzi D, Monestiroli S, Pratesi G, Limonta P. Activation of the orphan nuclear receptor RORalpha induces growth arrest in androgen-independent DU 145 prostate cancer cells. Prostate. 2001; 46:327-335.

14. Wu Y, Qi Y, Liu H, Wang X, Zhu H, Wang Z. AMPK activator AICAR promotes 5-FU-induced apoptosis in gastric cancer cells. Mol Cell Biochem. 2015.

15. Kim JG, Lee SJ, Chae YS, Kang BW, Lee YJ, Oh SY, Kim MC, Kim KH, Kim SJ. Association between phosphorylated AMP-activated protein kinase and MAPK3/1 expression and prognosis for patients with gastric cancer. Oncology. 2013; 85:78-85.
16. Kim YH, Liang H, Liu X, Lee JS, Cho JY, Cheong JH, Kim H, Li M, Downey TJ, Dyer MD, Sun Y, Sun J, Beasley EM, et al. AMPKalpha modulation in cancer progression: multilayer integrative analysis of the whole transcriptome in Asian gastric cancer. Cancer Res. 2012; 72:2512-2521.

17. Harris JM, Lau P, Chen SL, Muscat GE. Characterization of the retinoid orphan-related receptor-alpha coactivator binding interface: a structural basis for ligand-independent transcription. Mol Endocrinol. 2002; 16:998-1012.

18. Yamashita S, Tsujino Y, Moriguchi K, Tatematsu M, Ushijima T. Chemical genomic screening for methylationsilenced genes in gastric cancer cell lines using 5-aza-2'deoxycytidine treatment and oligonucleotide microarray. Cancer Sci. 2006; 97:64-71.

19. Lu Y, Yi Y, Liu P, Wen W, James M, Wang D, You M. Common human cancer genes discovered by integrated gene-expression analysis. PLoS One. 2007; 2:e1149.

20. Zhu Y, McAvoy S, Kuhn R, Smith DI. RORA, a large common fragile site gene, is involved in cellular stress response. Oncogene. 2006; 25:2901-2908.

21. Wang Y, Solt LA, Kojetin DJ, Burris TP. Regulation of p53 stability and apoptosis by a ROR agonist. PLoS One. 2012; 7:e34921.

22. Chauvet C, Vanhoutteghem A, Duhem C, Saint-Auret G, Bois-Joyeux B, Djian P, Staels B, Danan JL. Control of gene expression by the retinoic acid-related orphan receptor alpha in HepG2 human hepatoma cells. PLoS One. 2011; 6:e22545.

23. Xiong G, Wang C, Evers BM, Zhou BP, Xu R. RORalpha suppresses breast tumor invasion by inducing SEMA3F expression. Cancer Res. 2012; 72:1728-1739.

24. Kim H, Lee JM, Lee G, Bhin J, Oh SK, Kim K, Pyo KE, Lee JS, Yim HY, Kim KI, Hwang D, Chung J, Baek SH. DNA damage-induced RORalpha is crucial for p53 stabilization and increased apoptosis. Mol Cell. 2011; 44:797-810.

25. Yuan LW, Yamashita H, Seto Y. Glucose metabolism in gastric cancer: The cutting-edge. World J Gastroenterol. 2016; 22:2046-2059.

26. Byun JK, Choi YK, Kang YN, Jang BK, Kang KJ, Jeon YH, Lee HW, Jeon JH, Koo SH, Jeong WI, Harris RA, Lee IK, Park KG. Retinoic acid-related orphan receptor alpha reprograms glucose metabolism in glutamine-deficient hepatoma cells. Hepatology. 2015; 61:953-964.

27. Kang BW, Jeong JY, Chae YS, Lee SJ, Lee YJ, Choi JY, Lee IK, Jeon SW, Bae HI, Lee DK, Kwon OK, Chung HY, $\mathrm{Yu}$ W, et al. Phosphorylated AMP-activated protein kinase expression associated with prognosis for patients with gastric cancer treated with cisplatin-based adjuvant chemotherapy. Cancer Chemother Pharmacol. 2012; 70:735-741.

28. Zheng Z, Zheng Y, Zhang M, Wang J, Yu G, Fang W. Reciprocal expression of p-AMPKa and p-S6 is strongly 
associated with the prognosis of gastric cancer. Tumour Biol. 2016; 37:4803-4811.

29. Kim EJ, Yoon YS, Hong S, Son HY, Na TY, Lee MH, Kang HJ, Park J, Cho WJ, Kim SG, Koo SH, Park HG, Lee MO. Retinoic acid receptor-related orphan receptor alpha-induced activation of adenosine monophosphateactivated protein kinase results in attenuation of hepatic steatosis. Hepatology. 2012; 55:1379-1388.

30. Wang Z, Si X, Xu A, Meng X, Gao S, Qi Y, Zhu L, Li T, Li W, Dong L. Activation of STAT3 in human gastric cancer cells via interleukin (IL)-6-type cytokine signaling correlates with clinical implications. PLoS One. 2013; 8:e75788.

31. Wang Z, Dong L, Zhen Y, Wang Y, Qi D, Xu A, Meng X, $\mathrm{Li}$ W. Astragalus extract inhibits proliferation but enhances apoptosis in gastric cancer. Pak J Pharm Sci. 2016; 29:1473-1482.

32. Zha L, Wang Z, Tang W, Zhang N, Liao G, Huang Z. Genome-wide analysis of HMGA2 transcription factor binding sites by ChIP on chip in gastric carcinoma cells. Mol Cell Biochem. 2012; 364:243-251.

33. Yao H, Hwang JW, Moscat J, Diaz-Meco MT, Leitges M, Kishore N, Li X, Rahman I. Protein kinase C zeta mediates cigarette smoke/aldehyde- and lipopolysaccharide-induced lung inflammation and histone modifications. J Biol Chem. 2010; 285:5405-5416.

34. Calcagno DQ, Freitas VM, Leal MF, de Souza CR, Demachki S, Montenegro R, Assumpcao PP, Khayat AS, Smith Mde A, dos Santos AK, Burbano RR. MYC, FBXW7 and TP53 copy number variation and expression in gastric cancer. BMC Gastroenterol. 2013; 13:141.

35. Onoyama I, Tsunematsu R, Matsumoto A, Kimura T, de Alboran IM, Nakayama K, Nakayama KI. Conditional inactivation of Fbxw7 impairs cell-cycle exit during T cell differentiation and results in lymphomatogenesis. J Exp Med. 2007; 204:2875-2888.

36. Mendes-da-Cruz DA, Brignier AC, Asnafi V, Baleydier F, Messias CV, Lepelletier Y, Bedjaoui N, Renand A, Smaniotto S, Canioni D, Milpied P, Balabanian K, Bousso P, et al. Semaphorin 3F and neuropilin-2 control the migration of human T-cell precursors. PLoS One. 2014; 9:e103405.

37. Wang Z, Li W, Meng X, Jia B. Resveratrol induces gastric cancer cell apoptosis via reactive oxygen species, but independent of sirtuin1. Clin Exp Pharmacol Physiol. 2012; 39:227-232. 